\title{
How early should ankylosing spondylitis be treated with tumour necrosis factor blockers?
}

\author{
J Sieper, M Rudwaleit
}

Ann Rheum Dis 2005;64:iv61-iv64. doi: 10.1136/ard.2005.042432

Recognition and treatment of ankylosing spondylitis (AS) in the early stages of the disease has yet to be established. This paper considers the evidence available and the questions that need to be answered regarding the benefits of early diagnosis and treatment with tumour necrosis factor (TNF) blockers in AS. The authors conclude that AS can and has to be diagnosed earlier than is being done at present, before radiological changes are evident, and the potential of TNF blockers to induce long term remission if given early enough needs to be clarified.

\footnotetext{
A
} nkylosing spondylitis (AS) is an important chronic inflammatory disease with a prevalence between $0.5 \%$ and $1.0 \%,{ }^{12}$ which starts in about $80 \%$ of patients before the age of 30 years, ${ }^{3}$ thus early in life. Although temporary remissions and mild courses are part of the disease spectrum about $30 \%$ of patients have a constantly high disease activity over one year, as judged by a high disease activity index and elevated C-reactive protein. ${ }^{4}$ Furthermore, it has been estimated that at least $30 \%$ of patients do develop severe spinal restriction during the natural course of the disease. ${ }^{5}$ Socioeconomic costs can be high and increase with higher disease activity and lower function. ${ }^{6}$ Thus, effective early treatment should be focused on patients with high disease activity and on those who are likely to develop radiological progression and rapid functional deterioration during the natural course of their disease.

Until recently the treatment options for AS were limited. Regular physiotherapy and treatment with non-steroidal anti-inflammatory drugs (NSAIDs) were the only available symptomatic treatment. ${ }^{7}$ Other treatment options such as disease modifying antirheumatic drugs (DMARDs) or steroids, which are quite effective in other chronic inflammatory diseases such as rheumatoid arthritis, have no or only a limited effect. About $75 \%$ of patients with AS show a good or very good response to a full dose of NSAIDs in 48 hours, in contrast with only $15 \%$ of patients with mechanical back pain. ${ }^{8}$ Furthermore, a recent study has shown that patients with AS treated continuously over two years with a daily dose of NSAIDs had less radiological progression compared with those patients who took NSAIDs irregularly-that is, only on demand. ${ }^{9}$ Thus because of the good efficacy for acute symptoms and because of the potential to retard long term damage, AS patients with inflammatory back pain (in contrast with patients with mechanical low back pain) should be probably treated long term with NSAIDs-once the diagnosis is made and the disease is active.

However, about $20-50 \%$ of AS patients still have active disease despite treatment with NSAIDs. For these patients, tumour necrosis factor $\alpha$ (TNF $\alpha$ ) blocking agents have meant a breakthrough in treatment. Both the TNF blocking agents, infliximab and etanercept, have shown a surprisingly large and rapid effect on every aspect of active AS: disease activity including acute phase reactants, pain and morning stiffness, function, spinal mobility, peripheral arthritis, and enthesitis. ${ }^{10-13}$ In the different studies investigating these two compounds a $50 \%$ improvement of the disease activity was demonstrated in about half of the treated patients who were refractory to NSAID therapy and physiotherapy. Preliminary data indicate that the third TNF blocking agent, adalimumab, may be similarly effective. ${ }^{14}$ In parallel with a clear improvement in signs and symptoms, acute bony inflammation in the spine and sacroiliac joints, as detected by magnetic resonance imaging (MRI), was reduced impressively by this treatment. ${ }^{15-17}$

Thus, this high efficacy in patients otherwise refractory to treatment raises the question: How early in the course of their disease should these patients be treated with TNF blockers? In the last two decades an impressive paradigm shift in the treatment of rheumatoid arthritis took place. ${ }^{18}$ For this disease it has been demonstrated that with early and aggressive treatment even remission can be achieved in a substantial proportion of patients, ${ }^{19}$ and that radiological progression can be stopped and even healing of bony erosions occurs.

With regard to early treatment of AS with TNF blockers some questions need to be answered, and these will be addressed in this article.

\section{HOW CAN ANKYLOSING SPONDYLITIS BE DIAGNOSED EARLIER?}

A major obstacle to any early treatment is the big gap of 5-10 years between the first (chronic) symptoms of the disease and the diagnosis of the disease. ${ }^{3}$ One reason for this is certainly the low awareness of AS among non-rheumatologists. It is also a major challenge for any physician in primary care to think of and to identify patients with inflammatory spine disease among the large group of patients with chronic back pain. However, the relative late appearance of radiographic sacroiliitis, by up to several years after the first symptoms, is another important reason for this delay because usually the diagnosis is made according to the modified New York criteria; for this radiological sacroiliitis grade 2 bilaterally or grade 3 or 4 unilaterally is mandatory. However, it has become obvious, specially through the detection of acute sacroiliitis (and also inflammation of the spine) by MRI, that there is a continuum in spinal inflammation from a pre-radiographic to a radiographic stage (fig 1). We have argued recently that this should be treated as one disease, that radiological sacroiliitis should not be an essential diagnostic parameter but rather a measure of severity or chronicity, and that a diagnosis in the preradiographic stage can be made if a combination of clinical, laboratory, and imaging (especially MRI) parameters is applied. ${ }^{2021}$ Currently the ASessment in Ankylosing Spondylitis (ASAS) group is developing a new classification/diagnostic criteria for AS, which will also include the 


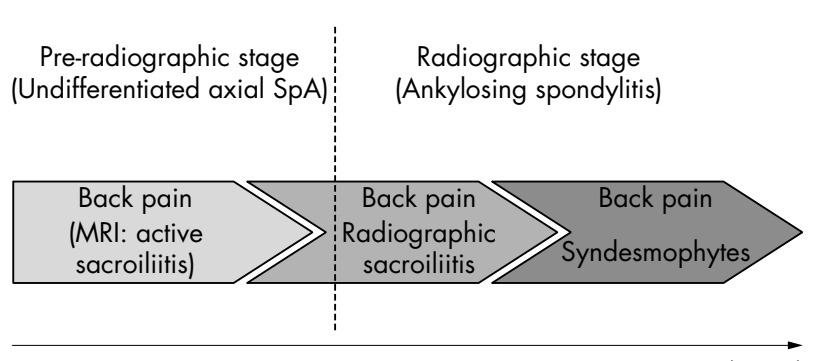

Time (years)

Figure 1 There is a continuous spectrum in patients with axial spondyloarthritis (SpA) from a pre-radiological stage to a radiological stage (classic ankylosing spondylitis) of the disease. Reproduced with permission from Rudwaleit M, Khan MA, Sieper J. The challenge of diagnosis and classification in early ankylosing spondylitis: do we need new criteria? [review] Arthritis Rheum 2005;52:1000-8, New Jersey: John Wiley and Sons, Inc.

early (pre-radiographic) forms of AS-an essential and crucial step for an early diagnosis.

\section{ARE PATIENTS EARLY IN THEIR DISEASE SIMILARLY ACTIVE COMPARED WITH LATER IN THE DISEASE?}

We have recently started a prospective cohort study of patients with early spondyloarthritides with special focus on AS (German Spondyloarthritis Inception Cohort (GESPIC)) in Germany. In this cohort we have included 120 AS patients (with radiographic sacroiliitis) with a disease duration between 5 and 10 years, 105 patients with a disease duration of less than 5 years and 200 patients with a predominant axial spondyloarthropathy (SpA) without radiographic sacroiliitis. The mean disease activity index (the Bath Ankylosing Spondylitis Disease Activity Index) and the mean level of pain in all three groups were exactly the same, demonstrating that the degree of signs and symptoms is already high early in the disease and independent of the presence or absence of radiological changes. ${ }^{22}$ Thus to alleviate the signs and symptoms, effective therapies have to be offered to patients early in the disease. Furthermore, on analysis of 99 AS patients treated with TNF blockers we were able to show that patients with a shorter disease duration have a better response rate compared with those patients with a longer disease duration: the percentage of patients with an at least $50 \%$ improvement of their disease activity

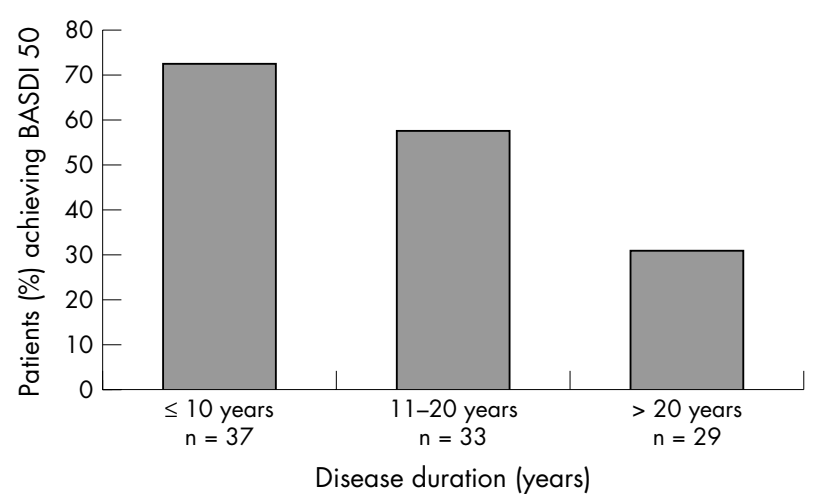

Figure 2 Patients with ankylosing spondylitis show a better response if treated with tumour necrosis factor blockers (infliximab or etanercept) early in the course their disease as judged by the percentage of patients showing a Bath Ankylosing Spondylitis Disease Activity Index (BASDAI) $50 \%$ improvement. Modified from Rudwaleit M, Listing J, Brandt J, Braun $\mathrm{J}$, Sieper J. Prediction of a major clinical response (BASDAI 50) to tumour necrosis alpha blockers in ankylosing spondylitis. Ann Rheum Dis 2004;63:665-70. was $73 \%$ for a disease duration less than 10 years, $58 \%$ for a disease duration between 10 and 20 years and only $31 \%$ for a disease duration of more than 20 years $^{23}$ (fig 2). This most probably reflects that symptoms early in disease are mainly due to inflammation whereas later in the disease symptoms are caused by a mixture of inflammation, structural spinal damage, and secondary damage to soft tissue such as muscles and ligaments.

\section{CAN RADIOLOGICAL PROGRESSION IN ANKYLOSING SPONDYLITIS BE STOPPED?}

Another major argument in favour of early treatment would be cessation of radiological progression, as has been shown in rheumatoid arthritis, in order to prevent disability. At the present time we only have preliminary evidence-from a comparison of radiological progression of the spine over a two year period between a group of patients treated with infliximab and the natural course of the disease in a control group over the same time-that this might be the case. ${ }^{24}$ The strongest evidence for such a potential of TNF blockers comes from MRI follow up studies during treatment with infliximab and etanercept. These studies have shown that acute inflammatory lesions in the spine and sacroiliac joints can be effectively suppressed (fig 3), ${ }^{15-17}$ also suggesting that bony destruction and bony proliferation can be prevented. However, such a link between acute inflammation and structural damage, although likely, has yet to be proved.

\section{ARE THERE PROGNOSTIC FACTORS THAT COULD PREDICT BAD OUTCOME?}

An effective treatment early in disease should be offered preferentially to patients with a bad prognosis. However, currently only a few studies are addressing this question. Amor et al undertook an analysis of 151 AS patients followed up retrospectively for 10 years and identified presence of hip arthritis, elevated erythrocyte sedimentation rate (ESR), and a bad response to NSAIDs as variables with the highest likelihood ratio to predict bad outcome. ${ }^{25}$ van der Heijde et al prospectively followed up 137 AS patients from the OASIS cohort and correlated measures at baseline with radiological progression of the spine after four years. ${ }^{26}$ They found that radiological damage at baseline, male sex, hip arthritis, and extraspinal manifestations such as uveitis and peripheral arthritis correlated best with structural damage. More data are expected in the near future from the analysis of ongoing cohort studies concentrating on patients with early disease.

\section{CAN REMISSION BE INDUCED IN ANKYLOSING SPONDYLITIS IF TREATMENT WITH TNF BLOCKERS IS STARTED EARLY?}

Treatment with TNF blockers has to be continued long term in most of the patients with established AS. We have recently shown that a relapse occurs after as short as a few weeks to a few months when treatment with infliximab ${ }^{27}$ or etanercept $t^{28}$ was discontinued in AS patients with a mean disease duration of more than 10 years. No data are available at the moment regarding whether remission is sustained after withdrawal of TNF blockers if patients are treated earlier, as has been suggested in rheumatoid arthritis. ${ }^{29}$ However, we have shown that remission can be achieved in a higher percentage of patients with shorter compared with longer disease duration (in $35 \%$ of patients with less than 10 years since first symptoms, but in none of the patients with more than 20 years and in only $24 \%$ of those with a disease duration between 10 and 20 years). ${ }^{23}$ Thus, patients early in the course of their disease clearly show a higher rate of remission if treated with infliximab or etanercept. Data are needed about the potential of such treatment to induce long term remission if patients are treated early. 

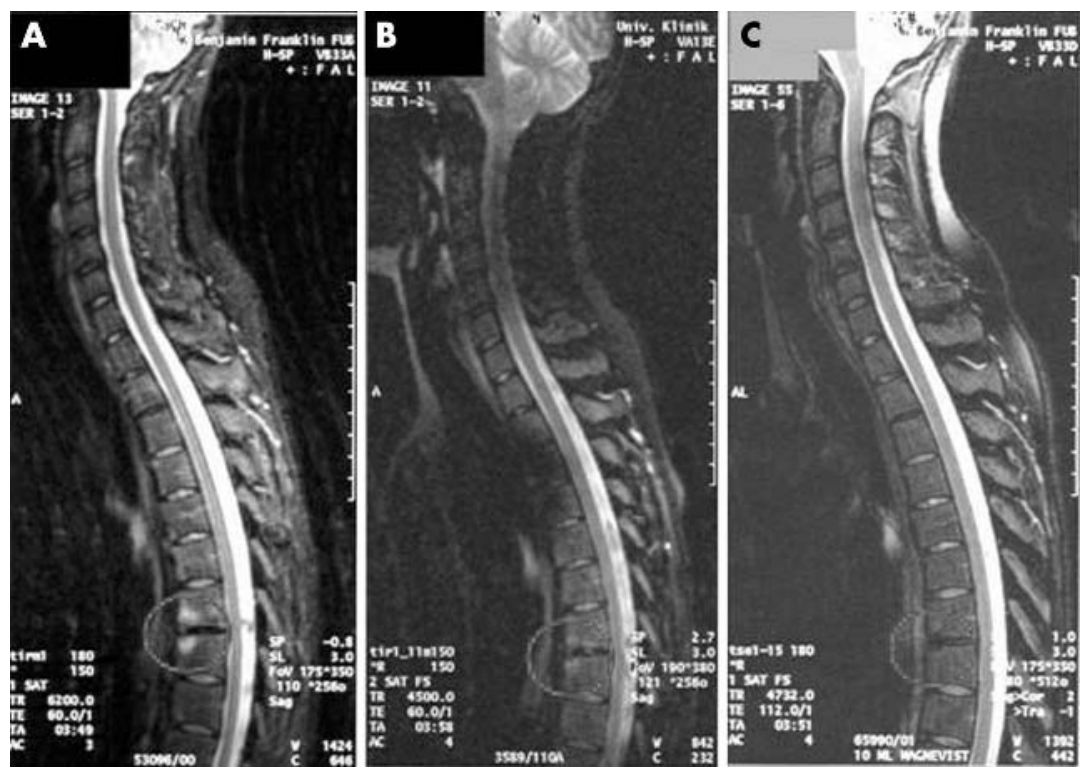

Figure $3 \quad(\mathrm{~A}-\mathrm{C})$ Magnetic resonance imaging (MRI) scan (STIR (short tau inversion recovery) technique) of the spine during treatment with infliximab $15 \mathrm{mg} / \mathrm{kg}$ body weight given every six weeks) showing disappearance of acute inflammation (anterior spondylitis). ${ }^{15}$

\section{HOW CAN PATIENTS WITH EARLY ANKYLOSING SPONDYLITIS BE BETTER IDENTIFIED IN PRIMARY CARE?}

Although there is some evidence that patients early in the course of their disease might benefit most from treatment with TNF blockers there are some open questions, which have been discussed here. These will only be addressed if these patients have a chance to be treated earlier. Thus, strategies have to be developed to alert the primary care physician when to think of inflammatory spine disease in patients with chronic back pain and when to refer these patients to the rheumatologist for a definite diagnosis. Most of the data on treatment of early rheumatoid arthritis have been raised in the last 10-15 years following the introduction of early arthritis clinics in many parts of the world. We have also recently proposed screening measures for early referral which are easy to apply. ${ }^{30}$ Such measures have to be sensitive and specific for the disease under consideration, easy to apply by the non-specialist, and should not be too expensive. We have calculated that a diagnosis of axial SpA can be made in every third to fifth patient who fulfils the criteria for the clinical symptom of inflammatory back pain, or is positive for human leucocyte antigen (HLA)-B27, or shows evidence of sacroiliitis by imaging. A wider application of such screening measures will enable us to make earlier diagnosis and gain more experience in treating these patients earlier with TNF blockers.

\section{SUMMARY}

In summary, AS can and has to be diagnosed earlier than is being done at present, even before radiological changes are evident. Therapies such NSAIDs and TNF blockers are most effective for the signs and symptoms that are caused by inflammation. This is probably a major reason why these drugs are so effective if used early in the course of the disease. The disappearance of inflammation in the spine and sacroiliac joints during treatment, as detected by MRI, is a demonstration of the great efficacy of the TNF blockers and also suggests that structural damage may also be prevented. Whether and how these new treatments also have the potential to induce long term remission if given early enough has to be shown in the future.

\section{Authors' affiliations}

J Sieper, M Rudwaleit, Medical Department, Rheumatology, Campus Benjamin Franklin, Charité, Hindenburgdamm 30, 12200 Berlin, Germany

Competing interests: none declared

Correspondence to: J Sieper; Joachim.sieper@charite.de

\section{REFERENCES}

1 Johnsen K, Gran JT, Dale K, Husby G. The prevalence of ankylosing spondylitis among Norwegian Samis (Lapps). J Rheumatol 1992;19:1591-4. 2 Braun J, Bollow M, Remlinger G, Eggens U, Rudwaleit M, Distler A, et al. Prevalence of spondylarthropathies in HLA-B27 positive and negative blood donors. Arthritis Rheum 1998;41:58-67

3 Feldtkeller E, Khan MA, van der Heijde D, van der Linden S, Braun J. Age at disease onset and diagnosis delay in HLA-B27 negative vs. positive patients with ankylosing spondylitis. Rheumatol Int 2003;23:61-6 [Epub 3 September 2002].

4 Rudwaleit M, Niewerth M, Listing J, Maerker-Hermann E, Zeidler H, Zink A, et al. Disease activity over one year in early ankylosing spondylitis in an observational cohort study (GESPIC) [abstract]. Ann Rheum Dis 2005;64:65.

5 Carette S, Graham D, Little H, Rubenstein J, Rosen P. The natural disease course of ankylosing spondylitis. Arthritis Rheum 1983;26:186-90.

6 Kobelt G, Andlin-Sobocki P, Brophy S, Jonsson L, Calin A, Braun J. The burden of ankylosing spondylitis and the cost-effectiveness of treatment with infliximab (Remicade). Rheumatology (Oxford) 2004;43:1 158-66.

7 Dougados M, Dijkmans B, Khan M, Maksymowych W, van der Linden S, Brandt J. Conventional treatments for ankylosing spondylitis [review]. Ann Rheum Dis 2002;61(suppl 3):iii40-iii50.

8 Amor B, Dougados M, Listrat V, Menkes CJ, Roux H, Benhamou C, et al. Are classification criteria for spondylarthropathy useful as diagnostic criteria? Rev Rhum Engl Ed 1995;62:10-15.

9 Wanders A, van der Heijde D, Landewé R, Behier J-M, Calin A, Olivieri I, et al. Non-steroidal anti-inflammatory drugs reduce radiographic progression in patients with ankylosing spondylitis: a randomized controlled trial. Arthritis Rheum 2005;52:1756-65.

10 Braun J, Brandt J, Listing J, Zink A, Alten R, Golder W, et al. Treatment of active ankylosing spondylitis with infliximab: a randomised controlled multicentre trial. Lancet 2002;359:1187-93.

11 van der Heijde D, Dijkmans B, Geusens P, Sieper J, DeWoody K, Williamson P, et al. Ankylosing Spondylitis Study for the Evaluation of Recombinant Infliximab Therapy Study Group. Efficacy and safety of infliximab in patients with ankylosing spondylitis: results of a randomized, placebo-controlled trial (ASSERT), Arthritis Rheum 2005;52:582-91.

12 Brandt J, Khariouzov A, Listing J, Haibel H, Sorensen H, Grassnickel L, et al. Six-month results of a double-blind, placebo-controlled trial of etanercept treatment in patients with active ankylosing spondylitis. Arthritis Rheum 2003;48: 1667-75

13 Calin A, Dijkmans BA, Emery P, Hakala M, Kalden J, Leirisalo-Repo M, et al. Outcomes of a multicentre randomised clinical trial of etanercept to treat ankylosing spondylitis. Ann Rheum Dis 2004;63:1594-600.

14 Haibel H, Rudwaleit M, Brandt H, Listing J, Grozownovic Z, Kupper H, et al. Adalimumab reduces spinal symptoms in active ankylosing spondylitis- 
clinical and MRI results of a 52 week open label trial. Arthritis Rheum 2005 (in press).

15 Braun J, Baraliakos X, Golder W, Brandt J, Rudwaleit M, Listing J, et al. Magnetic resonance imaging examinations of the spine in patients with ankylosing spondylitis, before and after successful therapy with infliximab: evaluation of a new scoring system. Arthritis Rheum 2003;48:1126-36.

16 Rudwaleit M, Baraliakos X, Listing J, Brandt J, Sieper J, Braun J. Magnetic resonance imaging of the spine and the sacroiliac joints in ankylosing spondylitis before and during therapy with etanercept. Ann Rheum Dis 2005;64:305-10.

17 Baraliakos X, Davis J, Tsuji W, Braun. Magnetic resonance imaging examinations of the spine in patients with ankylosing spondylitis before and after therapy with the fumor necrosis factor alpha receptor fusion protein etanercept. Arthritis Rheum 2005:52:1216-23.

18 Keen HI, Emery P. How should we manage early rheumatoid arthritis? From imaging to intervention. Curr Opin Rheumatol 2005; 17:280-5.

19 Klareskog L, van der Heijde D, de Jager JP, Gough A, Kalden J, Malaise M, et al. TEMPO (Trial of Etanercept and Methotrexate with Radiographic Patient Outcomes) study investigators. Lancet 2004;363:675-81.

20 Rudwaleit M, van der Heijde D, Khan MA, Braun J, Sieper J. How to diagnose axial spondyloarthritis early. Ann Rheum Dis 2004;63:535-43.

21 Rudwaleit M, Khan MA, Sieper J. The challenge of diagnosis and classification in early ankylosing spondylitis: do we need new criteria? [review] Arthritis Rheum, 2005;52:1000-8.

22 Rudwaleit M, Listing J, Maerker-Hermann E, Zeidler H, Braun J, Sieper J. The burden of disease in patients with ankylosing spondylitis and preradiographic axial spondyloarthritis is similar. Arthritis Rheum 2004;50(suppl 9):S211.
23 Rudwaleit M, Listing J, Brandt J, Braun J, Sieper J. Prediction of a major clinical response (BASDAI 50) to tumour necrosis factor alpha blockers in ankylosing spondylitis. Ann Rheum Dis 2004;63:665-70.

24 Baraliakos X, Listing J, Rudwaleit M, Brandt J, Sieper J, Braun J. Radiographic progression in patients with ankylosing spondylitis after two years of treatment with the tumor necrosis factor-a antibody infliximab. Ann Rheum Dis 2005 (in press). [Epub ahead of print 18 March 2005].

25 Amor B, Santos RS, Nahal R, Listrat V, Dougados M. Predictive factors for the longterm outcome of spondyloarthropathies. J Rheumatol 1994:21:1883-7.

26 van der Heijde $D$, Wanders A, Mielants $H$, Dougados $M$, Landewè RBM. Prediction of progression of radiographic damage over 4 years in patients with ankylosing spondylitis [abstract]. Ann Rheum Dis 2004;63(suppl 1):98.

27 Baraliakos X, Listing J, Brandt J, Rudwaleit M, Sieper J, Braun J. Clinical response to discontinuation of anti-TNF therapy in patients with ankylosing spondylitis after 3 years of continuous treatment with infliximab. Arthritis Res Ther 2005;7:R439-44.

28 Brandt J, Listing J, Haibel H, Sorensen H, Schwebig A, Rudwaleit M, et al. Long-term efficacy and safety of etanercept after readministration in patients with active ankylosing spondylitis. Rheumatology (Oxford) 2005:44:342-8.

29 Quinn MA, Conaghan PG, O'Connor PJ, Karim Z, Greenstein A, Brown A, et al. Very early treatment with infliximab in addition to methotrexate in early, poor-prognosis rheumatoid arthritis reduces magnetic resonance imaging evidence of synovitis and damage, with sustained benefit after infliximab withdrawal: results from a twelve-month randomized, double-blind, placebocontrolled trial. Arthritis Rheum 2005;52:27-35

30 Sieper J, Rudwaleit $M$. Early referral recommendations for ankylosing spondylitis (including pre-radiographic and radiographic forms) in primary care. Ann Rheum Dis 2005;64:659-63. 